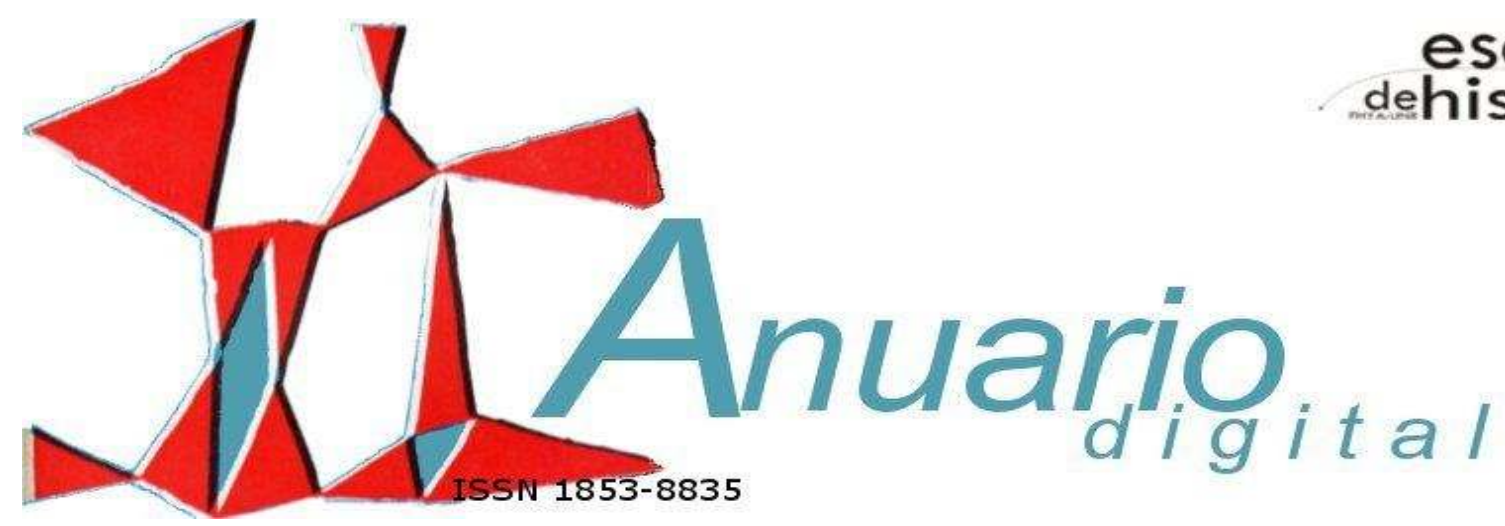

\title{
DE LAS SOCIEDADES DE OFICIO A LA UNIDAD DE CLASE: LOS PRIMEROS INTENTOS FEDERATIVOS DEL MOVIMIENTO OBRERO DE BUENOS AIRES, 1890-1896
}

En los últimos quince años del siglo XIX se produjo un salto decisivo en la consolidación de sociedades gremiales entre los trabajadores de Buenos Aires. El fortalecimiento de vínculos organizativos no se limitó, de todas formas, a las diferentes asociaciones de oficio. Muy pronto esas sociedades gremiales de diferentes gremios establecieron relaciones entre sí: no solo porque en todo momento jugó un papel destacado el ejemplo de los gremios más avanzados para estimular a la acción a los más rezagados, sino porque además muy tempranamente se planteó el problema de avanzar en una articulación de las distintas sociedades. Este artículo aborda un análisis de estos primeros intentos federativos, que jugaron un papel importante en la historia del movimiento obrero local.

Palabras clave: Federación obrera - movimiento obrero argentino - socialismo - anarquismo

\footnotetext{
* Instituto de Investigaciones Gino Germani, Universidad de Buenos Aires - CONICET.
} 
In the last fifteen years of the 19th century a leap forward in the consolidation of trade unions took place among the workers of Buenos Aires. The strengthening of organizational links was not limited, however, to each trade. Very soon these different trade unions established links between them, not only because the most advanced trades stimulated the weaker ones but also because the problem of establishing an articulation of all trades was set forth. This paper focuses on the first of those articulation efforts, which played a key role in the history of local labor movement.

Key words: Workers federation - labor movement - socialism - anarchism

El proceso de consolidación de sociedades gremiales de resistencia que tuvo lugar desde fines de la década de 1880 implicó un avance en la delimitación de una identidad de clase de un amplio sector de trabajadores de Buenos Aires. Agrupados en torno a asociaciones que, más allá de su heterogeneidad y sus diferencias, tenían en común el hecho de unir a los obreros para llevar adelante un enfrentamiento con los empresarios, se afianzó un sentido de pertenencia al propio oficio pero que implicaba también una creciente interpretación de sí mismos como parte de una clase obrera que tenía una unidad que excedía a las diferencias corporativas de cada gremio.

En este proceso, que se desarrolló al calor de la creciente conflictividad huelguística, jugaron un papel los primeros intentos hechos por grupos de militantes por comenzar a tender vínculos entre las diferentes sociedades gremiales. Los primeros en darle impulso a este tipo de iniciativas fueron los militantes socialistas, que en 1890, 1894 y 1895 intentaron impulsar una Federación obrera que no pudo sostenerse en el tiempo pero tuvo el indiscutible mérito de plantear la necesidad de la unidad de la clase obrera. Pero incluso desde las filas opositoras a los socialistas se planteó la cuestión de la articulación entre los diferentes gremios. Un conjunto de sociedades que se nuclearon en torno al periódico La Unión Gremial, y confluirían poco después en la experiencia de la llamada "Convención obrera", ofrecían una caracterización y una línea de intervención distinta, cuyo análisis resulta fundamental para obtener una mirada de conjunto de las discusiones y debates que recorrían al movimiento obrero en el período en torno a la cuestión de la unidad de clase y la huelga general.

Si bien, como veremos, los intentos federativos de la década de 1890 no resultaron exitosos, su estudio resulta importante porque ocuparon un lugar en el proceso de articulación de los diferentes

\section{8}

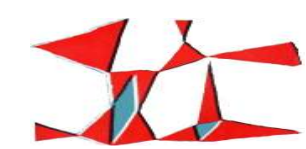

Anuario № 25, Escuela de Historia

Revista Digital № 4, Facultad de Humanidades y Artes, Universidad Nacional de Rosario, 2013

ISSN 1853-8835 
gremios y en la toma de conciencia de muchos trabajadores de su pertenencia a un movimiento que excedía las diferencias de oficio y los unía en tanto explotados por el capital. Se trata de un tema que ha sido escasamente abordado por la historiografía: luego de las primeras contribuciones de la llamada "historiografía militante", ${ }^{1}$ el papel jugado por las organizaciones sindicales y las federaciones obreras pasó a jugar un papel relativamente secundario en una producción que, sobre todo durante la década de 1980, se preocupó más por estudiar otros aspectos de la situación del llamado "mundo de los trabajadores" en la clave de la historia social. ${ }^{2}$ Consideramos que es importante volver a dirigir nuestra atención a la dinámica de organización gremial y federativa en este período temprano para poder superar los límites de los "historiadores militantes" de mediados del siglo XX, preocupados por lo general por relatar los antecedentes de la constitución de la propia corriente política a la que pertenecían, y al mismo tiempo para enriquecer el análisis del proceso de estructuración de la clase obrera local con una perspectiva que combine las inquietudes de la historia social y la historia política de los trabajadores.

\section{La primera Federación obrera, 1890-1892}

Hasta cierto punto las vicisitudes de la primera Federación obrera de 1890-1892 son parte de dos historias: la de los diferentes intentos por conformar una unidad entre los distintos gremios y la de los orígenes del socialismo argentino. Si más adelante ambos seguirán un camino relativamente independiente, en 1890-1892 aún no se había desarrollado un nucleamiento político independiente de los socialistas locales, y el grupo de militantes impulsores de la manifestación del 10 de Mayo de 1890 pretendió darse una organización que era al mismo tiempo de tipo gremial y política. ${ }^{3}$

\footnotetext{
${ }^{1}$ Abad de Santillán, Diego; El movimiento anarquista en la Argentina. Desde sus comienzos hasta el año 1910; Argonauta; Buenos Aires; 1930. Ídem; La FORA: ideología y trayectoria del movimiento obrero revolucionario en la Argentina; Buenos Aires; 1934. Oddone, Jacinto; Historia del Socialismo Argentino; La Vanguardia; Buenos Aires; 1934. Ídem; Gremialismo proletario argentino; La Vanguardia; Buenos Aires; 1949 y Marotta, Sebastián; El movimiento sindical argentino. Su génesis y desarrollo, 1857-1907; Editorial Lacio; Buenos Aires; 1960.

${ }^{2}$ Una excepción, aunque de todas formas se concentra en un período posterior al que examinamos aquí, es el trabajo de Bilsky, Edgardo; La FORA y el movimiento obrero; CEAL; Buenos Aires; 1985.

${ }^{3}$ La manifestación del $1^{\circ}$ de Mayo de 1890 ha sido trabajada en la historiografía. Ver, entre otros: Contreras, Miguel; El $1^{\circ}$ de $M a y o$ en la Argentina. Notas sobre sus orígenes, significado y proyecciones; Editorial Problemas; Buenos Aires; 1941. Iscaro, Rubens; Breve historia del $1^{\circ}$ de Mayo; Anteo; Buenos Aires; 1961. Viguera, Aníbal; "El 1 de Mayo en Buenos Aires, 1890-1950. Evolución y usos de una tradición"; Boletín del Instituto Ravignani; tercera serie, № 3; 1991 y Poy, Lucas; "Socialismo y anarquismo en los orígenes del Primero de Mayo en Argentina (1890-1895)"; Trabajadores. Ideologías y experiencias en el movimiento obrero; Año 1, № 2; segundo semestre de 2011.
}

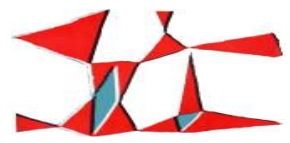

Anuario № 25, Escuela de Historia Revista Digital № 4, Facultad de Humanidades y Artes, Universidad Nacional de Rosario, 2013 ISSN 1853-8835 
En el número 3 de El Obrero, del 9 de enero de 1891, se publicaron los estatutos de una Federación que pretendía surgir como continuidad del comité obrero que había organizado el acto de mayo y había lanzado la publicación de ese primer periódico socialista en español. Eran muy extensos: incluían 9 "capítulos" y 21 artículos y contaban con un nivel de detalle que no se condecía con la debilidad organizativa y estructural de la organización. El artículo 1 señalaba que el objeto de la Federación era "realizar la unión de los obreros de esta Región, para defender sus intereses morales y materiales, practicar la solidaridad con los hermanos de todas las regiones en lucha contra el capital y sus monopolizadores, lucha reconocida como uno de los medios para llegar a la completa emancipación del trabajo". A continuación se establecía que los principales "medios de defensa de los intereses obreros" eran la "organización de todos los trabajadores por secciones de oficios y sociedades puramente obreras", "la solidaridad en todos los casos en que se presente la lucha por los intereses obreros" y "la propaganda e instrucción por medio de la prensa, bibliotecas, conferencias, folletos, etc". Se establecía luego una compleja estructura organizativa, con "federaciones locales" que estarían compuestas por sociedades de oficios de distrito y deberían elegir un comité encargado de ponerse "en relación continua con el Comité Federal", integrado por once miembros "elegidos anualmente por el congreso de delegados". El estatuto incluía además detalladas disposiciones sobre la periodicidad que debían tener las reuniones de los comités, la forma de elección de los delegados al congreso y la revocación del Comité Federal. El artículo 22 establecía que la Federación declaraba "día de fiesta obrera el 1ㅇ de Mayo para todos los trabajadores de la Región Argentina". ${ }^{4}$

En realidad, era la propia debilidad de la naciente Federación lo que explicaba ese nivel de detalle en los aspectos organizativos: en la medida en que no debían conciliar a diversos grupos ya existentes, como ocurriría más tarde, los impulsores del primer intento federativo se permitieron desarrollar un planteo organizativo muy elaborado, basado en lo que creían el funcionamiento "ideal" de una organización obrera de estas características. La Federación contaba apenas con la participación de las sociedades de

\footnotetext{
${ }^{4}$ El Obrero; № 3; 9 de enero de 1891. Dos semanas más tarde, se publicó el Reglamento de la Federación local de Buenos Aires, en la práctica la única de las "federaciones locales" que tendría un funcionamiento real. También era muy extenso, con 28 artículos y disposiciones detalladas de tipo administrativo y organizativo. El artículo 4 establecía la creación de una Sección varia "formada con todos los obreros que deseen pertenecer a la Federación y que aun no hayan constituido la Sección respectiva del oficio a que pertenecen", que se convertiría en el eje de la Federación, hasta ser prácticamente la única existente, debido a la ausencia de sociedades de oficios afiliadas.
}

230

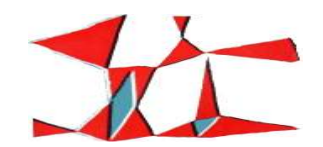

Anuario № 25, Escuela de Historia

Revista Digital № 4, Facultad de Humanidades y Artes, Universidad Nacional de Rosario, 2013 ISSN 1853-8835 
cigarreros, de "carpinteros, ebanistas y oficios varios" y de los "tipógrafos alemanes", además de algunas "secciones varias" que incluían a trabajadores de diferentes oficios que no contaban con una sociedad propia de su gremio. Entre sus dirigentes sobresalían los militantes socialistas, como el carpintero Carlos Mauli, el tipógrafo Augusto Kühn y el periodista José Winiger. A poco de formarse, en efecto, la Federación comenzó a sufrir las dificultades que planteaba la crisis económica, con su secuela de desocupación y reflujo de la conflictividad. En el mes de abril el periódico de la Federación reconocía que había sido un año "de muchas dificultades", particularmente luego de la Revolución del Parque, aunque se mostraba optimista en que el trabajo "no fuera en vano". ${ }^{5}$

En su breve existencia, la Federación dedicó una gran parte de sus esfuerzos a la presentación de peticiones y solicitudes a diversos poderes públicos del Estado, reclamando su intervención en el plano de la legislación y la administración para el mejoramiento de las condiciones de vida y trabajo de los obreros. En un lapso de dos años, la Federación elaboró peticiones que fueron presentadas al Congreso de la Nación, al propio presidente Pellegrini en forma directa y al Concejo Deliberante de la ciudad de Buenos Aires. La primera de estas presentaciones fue el petitorio trabajado durante la preparación de la movilización realizada el 1ㅇde mayo de 1890. El objetivo de la petición era solicitar "leyes protectoras a la clase obrera", en torno a las principales reivindicaciones de los trabajadores: jornada de ocho horas, prohibición del trabajo infantil, abolición del trabajo nocturno (excepto en aquellos oficios en que no fuera posible), prohibición del trabajo de las mujeres "en todos los ramos de la industria que afecten con particularidad al organismo femenino", descanso ininterrumpido de 36 horas, una vez por semana, prohibición del trabajo a destajo, inspección de talleres y fábricas por delegados estatales con participación obrera y seguro contra accidentes. $^{6}$

El programa tomaba así prácticamente todas las reivindicaciones que desenvolverían en sus conflictos los trabajadores de Buenos Aires del período: superando el plano de las luchas puramente salariales, planteaba el problema de la reducción de la jornada, la abolición del trabajo a destajo, la prohibición del trabajo infantil, la reglamentación de las condiciones laborales, etc. Durante los meses siguientes, la presentación enviada al Congreso motivó numerosos artículos en El Obrero que desarrollaban

\footnotetext{
5 “La Federación obrera y la burguesía argentina”; El Obrero; № 18; 25 de abril de 1891.

6 "Petición de obreros"; La Prensa; 23 de julio de 1890.
}

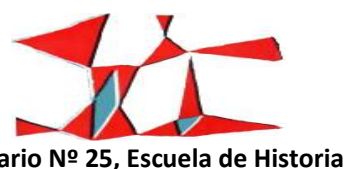


extensas justificaciones sobre la legitimidad de cada uno de los reclamos. Este avance programático del núcleo fundador de la Federación obrera no debe ser soslayado por el hecho de que la petición fuera rechazada sin más trámite en el Congreso y de que la propia Federación languideciera sin poder llevar adelante luchas importantes, en ese contexto de reflujo, para conquistar las reivindicaciones.

En enero de 1891, la Federación presentó un extenso texto al presidente Carlos Pellegrini. Allí se hacía una pormenorizada caracterización del impacto de la crisis sobre la clase trabajadora local, que mencionaba desde la carestía y el desempleo que afectaban coyunturalmente a los obreros hasta las deplorables condiciones de vida, trabajo y vivienda en la metrópoli. La Federación intervenía también en debates de política económica, criticando los proyectos proteccionistas que estaban en curso en el Parlamento, sosteniendo -como sería habitual en los planteos socialistas de la época, incluso a nivel internacional- una defensa del librecambio como argumento para respaldar un abaratamiento de los medios de consumo de los trabajadores. La nota enviada por la Federación recordaba la presentación hecha el año anterior, respaldada por las firmas de más de ocho mil trabajadores, y concluía con una apelación directa a la intervención del presidente en defensa de los intereses de los trabajadores:

Todavía el pueblo trabajador cree posible que V.E. al fin romperá con las funestas tradiciones hispano-americanas, protegerá el trabajo, acate el capital, el maestro y dominador de todo el mundo. Liquidación de los bancos oficiales y de los negocios de sus deudores, un sistema de contribución directa progresivas y de libre cambio, libertad del sufragio universal, naturalización de los extranjeros, para que todas las clases tomen parte en la legislación y en el "self-government", más amplio de las comunas: siguiendo este camino S.E. sería el salvador de este país, el Washington argentino. $^{7}$

Casi un año más tarde, en febrero de 1892, la Federación hizo una tercera presentación a los poderes públicos: esta vez se trató de la entrega a la municipalidad porteña de un proyecto para la creación de una "bolsa de trabajo". La presentación incluía una denuncia sobre el impacto de la crisis en la situación de los trabajadores: dirigida a la municipalidad, la solicitud estaba de todas formas redactada en términos moderados y, hasta cierto punto, conservadores. Planteaba que

\footnotetext{
7 “La cuestión social. Federación Obrera. Exposición al presidente de la República”; La Prensa; 16 de enero de 1891.

232

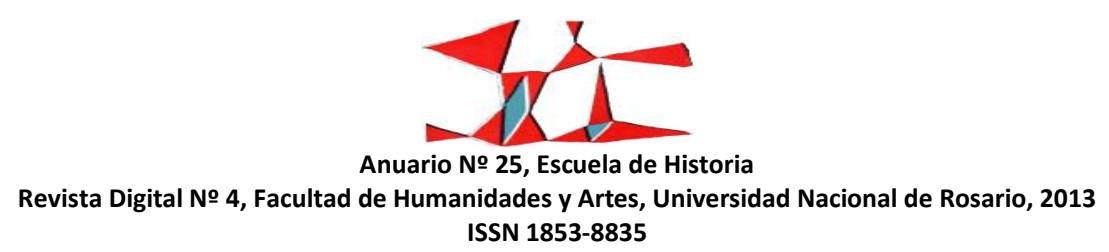


...el creciente malestar que sufre la clase trabajadora, podría traer la anarquía, lo que lamentaríamos profundamente como habitantes pacíficos que somos de la República Argentina (...) La Bolsa de Trabajo cuya fundación solicitamos del Honorable Concejo Deliberante ha sido puesta en práctica por la Municipalidad y Gobiernos de otros Estados con resultados satisfactorios (...) una institución de tal especie propende a establecer la armonía entre las clases sociales en lucha; contribuye asimismo a arrojar mucha luz sobre la cuestión social y a mejorar notablemente las condiciones de existencia de la clase proletaria.

La Federación "suplicaba" al Concejo la creación de una Bolsa de Trabajo "calcada sobre el modelo de las que ya existen en Italia y Francia", asegurando que tal medida no perjudicaría los intereses del municipio y solo afectaría a las agencias de colocación que entonces solían funcionar como intermediarias. El proyecto, por otra parte, reclamaba abiertamente una intervención de los organismos públicos, en este caso el municipio, en el funcionamiento de las organizaciones gremiales. Según la solicitud, la bolsa de trabajo tendría el objeto de "reunir en un solo establecimiento municipal todas las asociaciones gremiales existentes en la ciudad" y "ofrecerles un local decente en donde podrán reunirse con objeto de deliberar sobre los medios legales que pueden y deben tomarse para mejorar las condiciones de existencia, material e intelectual de los miembros de la clase asalariada". En ese espacio físico debería promoverse la "buena lectura", a través de conferencias y lecturas públicas, así como el desarrollo de conferencias populares y debates. Asimismo cada gremio podría hacer funcionar allí una "oficina de colocación" que serviría "gratuitamente de intermediaria entre el trabajador en busca de ocupación y de los patrones que ofrecen trabajo". ${ }^{8}$

En la misma línea de las presentaciones realizadas al Congreso y al presidente en los meses anteriores, la solicitud enviada al municipio ponía de manifiesto, en primer término, la importancia que daban los militantes socialistas al poder político como camino para lograr un verdadero mejoramiento de las condiciones de vida de los trabajadores. En este sentido las exigencias al gobierno y a los poderes legislativos buscaban poner de relieve que la "lucha económica" en la forma de huelgas no era sino una forma menos desarrollada de la acción obrera. En segundo lugar, de todas maneras, las peticiones públicas de la primera Federación obrera también ponían de manifiesto una cierta confianza en la respuesta que

\footnotetext{
${ }^{8}$ El Obrero; № 62; 28 de marzo de 1892.
}

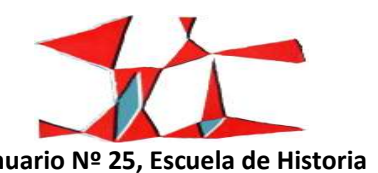


podría venir por parte de los gobiernos, que se iría desdibujando con el correr de los años, a medida que las repetidas presentaciones hechas a los organismos estatales cayeran permanentemente en saco roto. El énfasis en la importancia de la resolución política de la cuestión obrera seguirá presente, pero subrayando la necesidad de la acción política independiente de los trabajadores, organizados tras las banderas del socialismo, para llevar al parlamento a sus propios representantes, capaces precisamente de tomar las reivindicaciones que los de otros partidos no incorporaban.

En el mes de marzo de 1891 la Federación anunció su decisión de "suspender toda reunión mientras rija el estado de sitio", con excepción de las reuniones semanales del comité central, realizadas en el local del Vorwärts. Durante los meses siguientes, en efecto, la actividad pública de la Federación se redujo sustancialmente. Los esfuerzos de sus militantes se concentraron en la preparación del postergado primer congreso, que se realizaría a mediados de 1891. Como parte de los trabajos previos, la Federación impulsó la elaboración de una "estadística obrera", que se basaba en la elaboración de un cuestionario para cuya respuesta se pedía la colaboración de los "comités locales". La Federación también preparó, para su discusión en el congreso, un "reglamento sobre huelgas", uno de los primeros intentos por dejar sentada una posición acerca de una cuestión que dividiría fuertemente a las sociedades obreras en todo el período. El mismo establecía, en primer término, que era obligatorio para todas las sociedades que formasen parte de la Federación la creación de una "caja de resistencia" que se sustentara en una cuota obligatoria mensual de 10 centavos por parte de todos los asociados. El objetivo que se buscaba era evitar las huelgas derrotadas por falta de recursos: en el mismo sentido, el reglamento establecía explícitamente que ninguna sección debía declarar la huelga, excepto en los siguientes casos:

a) Cuando los patrones quisiesen violar un arreglo en que ambas partes hubiesen libremente consentido anteriormente. b) Cuando los patrones atentasen contra la persona o la libertad individual de algún obrero, o contra el derecho de asociación. c) Cuando un aumento del salario, o la disminución de las horas de trabajo se imponga con absoluta justicia y argumentos irrefutables, siempre que el estado de la plaza se presentase favorable. ${ }^{9}$

\footnotetext{
9 "Los obreros y las huelgas"; La Prensa; 22 de julio de 1891.

234
} 
Vemos cómo, en fecha tan temprana como 1891, los socialistas ya planteaban la posición que, más allá de algunas variantes, sostendrían con respecto a las huelgas en todo este período: para evitar las derrotas provocadas por la incapacidad de los diferentes gremios de resistir a la presión económica de la patronal, debían evitarse las declaraciones de huelgas generales, priorizando en cambio el método de las huelgas parciales de diferentes gremios particulares, que podrían así contar con el apoyo financiero de otros trabajadores que seguirían en actividad y estarían en condiciones de aportar al fondo de lucha.

El congreso se postergó dos veces: planeado originalmente para el fin de semana del 2 de agosto, se pasó primero para el 9 y terminó realizándose los días 15, 16 y 22. A pesar de la amplitud de la cobertura que habían tenido los preparativos en la prensa comercial, las crónicas que reseñaban las sesiones del congreso eran sumamente escuetas, poniendo de manifiesto que el mismo había revelado la debilidad de la joven Federación. El ambicioso orden del día, que incluía el informe del comité, la elección de una nueva comisión y la discusión de múltiples temas como las ocho horas de trabajo, el descanso hebdomadario, la situación de la mujer, el trabajo a destajo, las cajas de socorro, la reglamentación del trabajo agrícola y la determinación de la fecha del próximo congreso, contrastaba de manera brutal con la exigüidad de la convocatoria: tan solo quince delegados se hicieron presentes en la sesión inaugural. En ella se puso en evidencia, además "el infaltable desacuerdo entre los marxistas y los anarquistas", cuando los delegados de la sociedad de obreros panaderos se retiraron denunciando que tan "microscópico congreso" no podía tener ningún beneficio para la clase obrera.

El congreso continuó sus sesiones, sin superar nunca las dos docenas de delegados. La contracara de la debilidad organizativa de la naciente Federación era su decidida definición política en favor de los planteos socialistas. En efecto, el congreso resolvió designar una comisión encargada de formular "un programa análogo al de los partidos obreros europeos" y aprobó en forma unánime, a instancias de Augusto Kühn, una moción que consideraba "la propiedad individual de los medios de producción fuentes del malestar que soporta la clase obrera" y se manifestaba "en favor de la abolición completa de la propiedad individual, en conformidad con todos los partidos de todos los países". La deserción de la sociedad de panaderos, en el marco de la creciente disputa con el anarquismo que tenía lugar en 1891, no hizo más que reforzar esta orientación. En un artículo publicado en diciembre de 1891 en El Obrero se reivindicaba que la Federación hubiera "hecho franca y espontánea confesión de fe socialista",

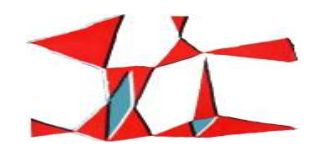

Anuario № 25, Escuela de Historia Revista Digital № 4, Facultad de Humanidades y Artes, Universidad Nacional de Rosario, 2013 ISSN 1853-8835 
considerando que con dicho posicionamiento ella "se ha declarado un Partido socialista, y aunque poco imponente todavía en cuanto a sus fuerzas y número de compañeros alistados en secciones gremiales organizados, es un partido poderoso e invencible por este carácter socialista mismo". Concluían señalando que "no importa tanto que la Federación sea imponente, lo que importa es que sea socialista". ${ }^{10}$

El segundo congreso de la Federación, realizado en octubre de 1892, tuvo una convocatoria aún más débil. Si bien siguieron ocupando un lugar las reivindicaciones económicas, en torno a la jornada de ocho horas, el trabajo de las mujeres y menores, la seguridad, la higiene en el trabajo, la inspección en los talleres, la igualdad en los salarios de hombres y mujeres, las definiciones políticas volvieron a tener un lugar destacado. El programa de acción partía de una caracterización de la sociedad capitalista de corte netamente marxista. En sus considerandos caracterizaba que la sociedad era "injusta, porque divide a sus miembros en dos clases desiguales y antagónicas", la burguesía y el proletariado, y sostenía que "el hecho de no poseer los productores -que son los trabajadores- los medios de producción, es la causa primera de la dependencia económica, y por consiguiente de la esclavitud en todas sus formas: la miseria social, el envilecimiento intelectual y físico y la dependencia política". En este cuadro, dado que "los privilegios de la burguesía capitalista están garantizados por el poder político", la respuesta del proletariado debía plantearse en ese mismo terreno. La Federación sostenía, así, que "la poderosa palanca con que el proletariado ha de destruir los obstáculos que a la transformación de la propiedad se oponen, ha de ser el poder político, del cual se vale la burguesía para impedir las reivindicaciones de los derechos del proletariado". ${ }^{11}$

El congreso de octubre de 1892, en realidad, tenía lugar cuando la experiencia de la primera Federación estaba llegando a su fin. La disolución formal de la Federación tendría lugar en una reunión realizada en el mes de diciembre, cuando la mayoría de los miembros de su "sección varia" -en los hechos la única que existía- decidió convertirse en “Agrupación Socialista”. La transformación de sociedad gremial en agrupación política era un reconocimiento de las dificultades que se habían encontrado en esa primera

\footnotetext{
10 "Nuestro primer año"; El Obrero; № 49; 26 de diciembre de 1891.

${ }^{11}$ Citado en Spalding, Hobart; La clase trabajadora argentina. Documentos para su historia; Galerna; Buenos Aires; 1970; pp. 114115.
}

236

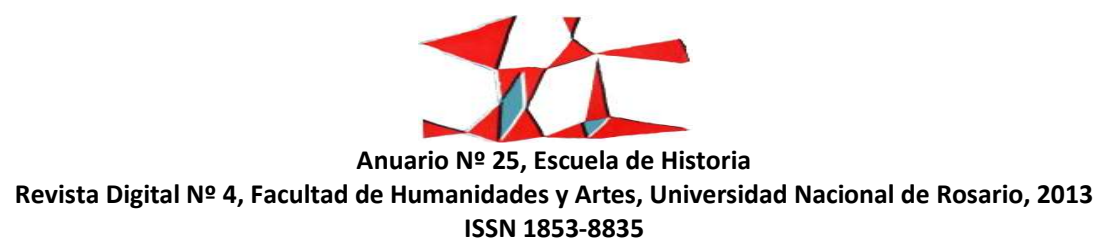


experiencia que había intentado construir una Federación obrera que al tiempo que nucleaba al conjunto de las sociedades gremiales desarrollaba un posicionamiento político abiertamente socialista.

\section{Los intentos federativos de 1894}

A pesar de que un sector minoritario se opuso a convertir la federación en una agrupación socialista y buscó mantener la organización en funcionamiento, la primera Federación obrera dejó de existir en los primeros meses de 1893. Fue con la recomposición de la agitación obrera, durante 1894, cuando tuvo lugar un nuevo intento de formar una federación que nucleara la actividad de las diferentes sociedades de resistencia activas en la ciudad, y una vez más los socialistas jugaron un papel destacado en su organización. En efecto, desde los primeros números de La Vanguardia, cuya primera edición apareció en abril de 1894, se hacía una valoración positiva del proceso de recomposición de las sociedades gremiales que estaba en curso. El periódico no se limitaba, sin embargo, a caracterizar el alentador cuadro de recomposición de las sociedades obreras, sino que llamaba a los militantes a ingresar en la sociedad gremial que les correspondiese para desenvolver en ella "abiertamente la idea revolucionaria y comunista", así como fundar sociedades en aquellos gremios que aún no la tuvieran, "para que desde su principio respondan genuinamente a esa idea". Por último, se trataba de "fomentar la federación de los distintos gremios, para que la acción de cada uno de ellos sea más segura y eficaz" ${ }^{12}$

Con esta perspectiva, los socialistas tomaron la iniciativa de reforzar los vínculos existentes entre las diferentes sociedades gremiales. La nueva federación, sin embargo, no fue, a diferencia de la interpretación difundida por la historiografía "canónica" del Partido, una iniciativa puramente socialista, sino que buscó inicialmente un compromiso con sociedades influenciadas por militantes de diferentes orientaciones políticas. ${ }^{13}$ En realidad, el intento de constituir una segunda Federación obrera debe analizarse en el marco

\footnotetext{
12 "En el buen camino"; La Vanguardia; № 3; 21 de abril de 1894

${ }^{13}$ La experiencia de los intentos federativos del período 1894-1896 ha sido escasamente estudiada. La mayor parte de las referencias corresponden a los trabajos "canónicos" de la historiografía del Partido Socialista - cuyo ejemplo más característico es la ya citada obra de Jacinto Oddone o los trabajos de Martín Casaretto-, en los cuales se presentan los avances organizativos de estos años tomando en cuenta únicamente la perspectiva de los militantes y gremios que respondían a su misma filiación y sin distinguir las dos etapas que, como veremos, es posible advertir en la experiencia federativa de estos años. En su trabajo sobre el anarquismo argentino Gonzalo Zaragoza fue quien realizó el mayor avance en la investigación del período, aportando una clasificación bastante precisa de los gremios que respondían a los socialistas y aquellos afines a los anarquistas aunque con
}

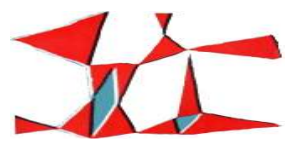

Anuario № 25, Escuela de Historia 
más amplio de movilización obrera que cobró impulso durante 1894 en torno a la huelga de los trabajadores de la industria de la construcción. El núcleo impulsor de la nueva Federación, en efecto, estaba formado por los delegados de las sociedades de albañiles, pintores, yeseros, escultores y herreros: si entre estos últimos es indudable que los socialistas jugaban un rol hegemónico, en las sociedades vinculadas a los gremios de la construcción la presencia de militantes de orientación anarquista era más notable.

Los primeros avances efectivos de la Federación tuvieron lugar con una serie de reuniones realizadas a mediados de 1894. El 9 de junio La Vanguardia publicó una nota del presidente de la sociedad de herreros y mecánicos que informaba sobre la realización de una primera reunión, a partir de una convocatoria hecha por su sociedad, "con el objeto de discutir las bases de la publicación de un periódico obrero". Según la nota, habían concurrido delegados de las sociedades de albañiles, pintores y yeseros, aunque éste "con carácter extra-oficial". Allí se resolvió convocar a una nueva reunión para el lunes 11 de junio, intentando ampliar la convocatoria a representantes de otras sociedades gremiales activas en la ciudad. Dicha reunión no resultó mucho más exitosa: además de los presentes en la primera convocatoria se sumaron delegados de la sociedad de escultores y herreros, y los yeseros mandaron una representación en regla. A pesar de la exigua convocatoria, y "después de un cambio general de ideas", "se procedió a la elección de una comisión, encargada de presidir las reuniones y formular el programa de la Federación obrera y consiguientes reglamentos". La misma estaba compuesta por un delegado de cada sociedad representada: sus miembros eran Patroni, Pedroni, Bonesada, Boglina y Canavesio, y acordó reunirse los días lunes en el local de la sociedad de herreros. ${ }^{14}$

Una semana más tarde se realizó una nueva reunión, que aprobó un "proyecto de programa" para la nueva Federación. En sus extensos considerandos, se denunciaban las gravosas condiciones de explotación sufridas por los trabajadores: particularmente los bajos salarios y el desempleo, consecuencia del "adelanto de la industria". Se denunciaba que el empleo de niños y mujeres en las fábricas era "causa de muchos males en las familias y de la disminución del ya escaso salario de los hombres". En la misma línea, se cuestionaba "el sistema de aprendizaje implantado para los niños", señalando que no solo era "uno de

numerosas imprecisiones en cuanto a fechas y alineamientos de las diferentes sociedades (Zaragoza, Gonzalo; Anarquismo argentino; De la Torre; Madrid; 1996).

14 "Movimiento obrero argentino"; La Vanguardia; № 10; 9 de junio de 1894. "Movimiento obrero argentino. Federación obrera"; La Vanguardia; № 11; 16 de junio de 1894.

238

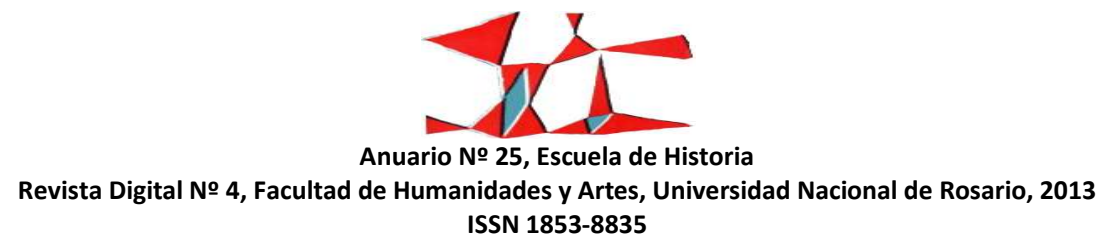


los tantos medios de explotación puestos en juego por los capitalistas" sino también un método "perjudicial a la salud y al desarrollo intelectual", incapaz de formar "obreros inteligentes y acabados" y cuyo único objeto era promover una "superabundancia de brazos", capaz de reducir los salarios. El proyecto de programa denunciaba que debido a las jornadas laborales excesivas los trabajadores carecían de tiempo para instruirse y desarrollarse intelectualmente, así como la ausencia de cualquier tipo de leyes protectoras de la clase obrera, que la defendieran de las "tiránicas pretensiones de los patrones". Se consideraba, por último, que "las huelgas gremiales y generales" no habían dado nunca "un resultado positivo o una mejora duradera", por lo cual era necesario "unirse todos los trabajadores con una sola aspiración, sus derechos y su bienestar".

A continuación de los considerandos se desarrollaba el programa, que constaba de dieciséis artículos. Definía a la Federación como "la unión de todas las colectividades trabajadoras en un pacto solemne de solidaridad y mutuo apoyo": su objetivo era "representar a las sociedades frente al capital", para asegurar que se cumpliesen los compromisos contraídos. Los artículos desenvolvían diferentes puntos programáticos que la Federación se planteaba como pasos inmediatos, entre los cuales figuraban "normalizar las cuestiones de horario y de salario", estableciendo la jornada de ocho horas para todos los oficios y recomendando el estudio de que los sueldos fueran pagados en oro; abolir el trabajo por hora y a destajo; reglamentar el trabajo de las mujeres y de los niños y "estudiar el medio de asegurar de una manera eficiente a los obreros contra los accidentes de trabajo y contra la falta de éste". Además de estas reivindicaciones, el programa de la Federación se planteaba la tarea de promover la organización de sociedades de resistencia en todos los gremios que aún no las tuvieran "y tratar de unir a todos los trabajadores en contra del capital", así como incentivar "un análogo movimiento en las provincias" y establecer lazos de solidaridad con federaciones de otros países. Se establecía además la intención de establecer "escuelas profesionales, periódicos y revistas", además de bibliotecas y círculos obreros que fomentaran la formación y aprendizaje de los trabajadores. El artículo 12 planteaba la fundación de una bolsa de trabajo "exclusivamente para los obreros que entren en la Federación". El artículo 14 dejaba sentada la intención de "intervenir ante los poderes públicos en todas las cuestiones de interés vital para los trabajadores y peticionar de ellos las mejoras que se consideren necesarias", mientras que el 15 establecía que la Federación se abstendría "de todas las cuestiones políticas y religiosas".

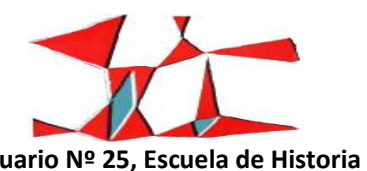


El último tramo del proyecto de programa estaba compuesto por algunos artículos organizativos, mucho menos puntillosos que en la Federación anterior. Se establecía que la nueva organización estaría compuesta por "todas y solamente las sociedades esencialmente de resistencia", y se permitía la creación de una "sección varia" compuesta por aquellos trabajadores "que por la naturaleza de su oficio, o por la escasez de número, no pueden formar una sociedad gremial”. Un "Comité Federal Central" estaría formado por delegados de cada sociedad, en un número y proporción que deberían establecer los reglamentos. ${ }^{15}$

Los socialistas celebraron el avance logrado pero criticaron el explícito abstencionismo político que se había adjudicado a la incipiente federación. La Vanguardia admitía que era ventajoso que la nueva federación no tuviera una abierta definición política, "porque así entrarán más fácilmente en ella muchos trabajadores que todavía no comprenden la táctica política del partido obrero", pero cuestionaba que este abstencionismo se presentara en la forma de una explícita prohibición respecto a la acción política. Por el momento la prohibición resultaba "superflua e inútil": en el futuro, "cuando los trabajadores inteligentes e instruidos, que comprenden la necesidad de la acción política, hayan formado aquí un partido obrero, esa prohibición impedirá a la federación tomar parte en un movimiento que le interesará en primera línea, o tendrá que modificar sus estatutos" ${ }^{16}$

Durante las semanas siguientes, en cualquier caso, el debate se trasladó a diferentes reuniones y asambleas de las distintas sociedades gremiales. Una de las discusiones más importantes fue, en este punto, la que tuvo lugar en una asamblea de la sociedad de resistencia de panaderos, realizada el 12 de julio. Según la crónica, la asamblea fue "muy numerosa y se manifestó más bien hostil que entusiasta para con el referido programa". El proyecto fue debatido artículo por artículo, y la sociedad resolvió hacer llegar a los impulsores de la Federación un conjunto de modificaciones y críticas. Uno de los principales ejes de cuestionamiento de los panaderos fue el artículo 14, que resultó rechazado: la asamblea de la sociedad

\footnotetext{
${ }^{15}$ Ver La Vanguardia; № 12; 23 de junio de 1894.

16 "Federación obrera argentina. Su programa”; La Vanguardia; № 12; 23 de junio de 1894. En sus manuscritos, Dardo Cúneo señalaba que debían entenderse estas limitaciones programáticas como resultado del compromiso que habían tenido que aceptar los socialistas, que buscaban impulsar una Federación en conjunto con militantes de otra orientación política. Si bien destacaba que el nuevo programa reproducía muchos de elementos presentes en el de la primera Federación, reconociendo que la huelga era un "método insuficiente" y que los trabajadores debían unirse para "la conquista de su emancipación", Cúneo ponía de relieve que "como tributo a la necesaria unión, los socialistas, que son mayoría entre los promotores, hacen renuncia de sus puntos de vista acerca de identificar a la rebelión obrera con un plan completo de acción y en el programa escriben esta garantía para los anarquistas sobre la conducta de la Federación: "se abstendrá de todas las cuestiones políticas y religiosas" (Archivo Dardo Cúneo, Biblioteca Nacional).
}

\section{0}

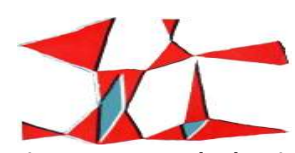

Anuario № 25, Escuela de Historia Revista Digital № 4, Facultad de Humanidades y Artes, Universidad Nacional de Rosario, 2013 ISSN 1853-8835 
consideró que la propuesta de peticionar ante los poderes públicos resultaba contraria al principio según el cual "la emancipación de los obreros tiene que ser obra de ellos mismos". Los panaderos, por otro lado, insistían en que no aceptaban "enrolarse bajo bandera socialista alguna" y deseaban conservar "la más amplia autonomía y descentralización para todas las sociedades de resistencia". En la misma línea, resolvieron sustituir el artículo que disponía el establecimiento de un Comité central y comités provinciales por el acuerdo, muchos menos centralizador, que había sido aprobado "en el pacto de confederación de las Sociedades de obreros panaderos en la República Argentina" y establecía que:

Cualquier sociedad confederada cuando reconozca necesario discutir asuntos de importancia, iniciará los trabajos para celebrar una reunión general de las sociedades confederadas. En el caso de no ser posible celebrar reunión general, por las dificultades de las distancias o por otros motivos, se procederá a la discusión del asunto por intermedio de cartas y cuando no sea posible resolver satisfactoriamente, se invitará a las sociedades confederadas a elegir delegados temporarios, para que se reúnan y discutan sobre el punto y lo resuelvan.

El resto del programa fue aprobado, "con la recomendación de estudiar si conviene suprimir el artículo referente al trabajo a destajo y estudiar largamente antes de establecer bibliotecas públicas, porque para esas bibliotecas son necesarias grandes sumas de dinero y también para su mantenimiento". ${ }^{17}$

Los cambios propuestos por la sociedad de panaderos fueron respondidos por los socialistas en su periódico: para La Vanguardia, era aceptable la modificación que planteaba que las federaciones locales no dependieran de la federación de la capital, en tanto "los asuntos que interesen a la clase obrera del país entero deben ser tratados por congresos o comisiones que representen a todas las federaciones". Las otras enmiendas, en cambio, eran caracterizadas como "muy imperfectas". Según los socialistas, el planteo descentralizador propugnado por los panaderos resultaría en un debilitamiento de la organización obrera. También salían al cruce de la crítica desarrollada por la sociedad de panaderos a la apelación a los poderes públicos. Para La Vanguardia,

...el hecho de que la emancipación de los trabajadores tiene que ser la obra de ellos mismos, no quiere decir que los obreros deban privarse de un arma tan útil como es el derecho de petición a los

\footnotetext{
17 “Movimiento obrero argentino"; La Vanguardia; № 22; 1 de septiembre de 1894.
}

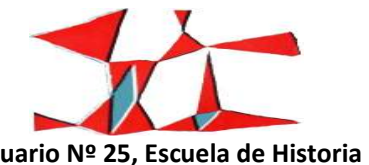


poderes públicos. Es bien sabido que siendo estos poderes gobiernos de clase, no han de ser muy grandes concesiones a los reclamos de la clase obrera. Pero siempre puede ser bueno reclamar y pedir, para mostrar una vez más que los gobiernos burgueses mienten cuando dicen que defienden al pueblo trabajador. ${ }^{18}$

El lunes 27 de agosto se convocó una nueva reunión en el local de los albañiles, pero la negativa de numerosas sociedades gremiales de la ciudad a sumarse a la iniciativa comenzaba a enfriar los ánimos y ponía de relieve que la constitución de una nueva Federación no era una tarea sencilla. El 8 de septiembre La Vanguardia publicó un extenso artículo, titulado "A propósito de programas y de reglamentos", que ponía de manifiesto las dificultades que estaba encontrando la nueva Federación para constituirse definitivamente y salir del impasse en el que había entrado a partir del debate sobre su programa. La reflexión del periódico socialista ponía de relieve, en primer término, la experiencia que habían recorrido los militantes socialistas desde la época de la primera Federación, que contaba como vimos con extensas reglamentaciones y disposiciones organizativas que habían excedido por mucho la realidad de las fuerzas con las que efectivamente contaba la naciente organización. Después del fracaso de aquella experiencia y de las dificultades que enfrentaba la nueva Federación para desarrollarse, La Vanguardia caracterizaba que en cuanto a reglamentos era "el sentido común" el que "debería ser la norma escrita de conducta para nuestras sociedades", en la medida en que las reglamentaciones no podían alcanzar a prever los asuntos más importantes y las dificultades que surgían de la vida de las sociedades. El periódico dejaba claro que estas reflexiones tenían lugar en el cuadro de las dificultades para avanzar en la constitución de la Federación:

(...) Un programa escrito, que no siempre es indispensable, viene a ser entonces una calamidad para la sociedad que lo está por adoptar; y un reglamento, un obstáculo para la buena marcha de la misma. Debemos acostumbrarnos a dedicar toda nuestra atención a los asuntos prácticos, de interés inmediato. Así adelantaremos más pronto, y no nos quedará tiempo para controvertir sobre puntos en que no estamos todos de acuerdo, y que, por consiguiente, nos dividen. ${ }^{19}$

\footnotetext{
18 Ídem.

19 "A propósito de programas y de reglamentos"; La Vanguardia; № 23; 8 de septiembre de 1894.
}

242

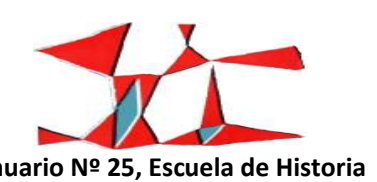


Ante las dificultades encontradas para consensuar un programa, en efecto, éste sería el camino adoptado por la naciente Federación. El 22 de septiembre La Vanguardia informaba que luego de varias reuniones de delegados se había llegado a la conclusión de que era mejor "prescindir de todo programa general y limitarse por el momento a una declaración de solidaridad entre las diferentes sociedades". Según este nuevo criterio, cada una de las sociedades podría proponer a las restantes las medidas que creyera convenientes y para su discusión se nombrarían delegados especiales y celebrarían convenios ad referéndum. La Vanguardia admitía que se trataba de un paso atrás respecto a sus objetivos originales. Según el periódico socialista, sin embargo, era un retroceso que se debía a la realidad del grado de desarrollo de las sociedades gremiales locales, cuya "comunidad de intereses y de opiniones no es todavía muy completa". ${ }^{20}$

El 20 de octubre Adrián Patroni insistió en la importancia de la Federación, en un artículo que volvía a convocar a todas las sociedades gremiales a debatir el problema a partir de una propuesta de programa enviada por la sociedad de pintores, que "si bien es muy lacónico abarca en sí todo lo que el buen sentido pueda dictar". Se trataba, en efecto, de un planteo modesto, que se limitaba a reclamar la solidaridad de unos gremios con otros: establecía que "cuando un gremio deseara obtener alguna mejoría, invitará a los demás gremios que estuvieran federados a nombrar sus delegados a fin de discutir el punto: estos darán cuenta a sus respectivas asambleas, las cuales aceptarán o rechazarán por voto secreto lo acordado en la reunión de delegados". Pero tampoco con este proyecto más limitado se logró un consenso: una semana más tarde el periódico reseñaba una reunión de gasistas, hojalateros y anexos que después de una amplia discusión habían decidido "no adherirse al proyecto de federación formulado por los pintores, considerándolo insuficiente para hacer efectiva la solidaridad entre los trabajadores". ${ }^{21}$

\section{Una articulación entre sociedades gremiales afines al socialismo: la Federación obrera de 1895}

Las diferencias entre las distintas sociedades de resistencia, que se expresaron particularmente en la oposición de aquellas que contaban con mayor influencia de militantes anarquistas a sumarse a una Federación que se veía dominada por los socialistas, impidieron que los avances realizados a mediados de

\footnotetext{
20 "Federación obrera"; La Vanguardia; № 25; 22 de septiembre de 1894.

21 "Movimiento obrero argentino"; La Vanguardia; № 30; 27 de octubre de 1894.
}

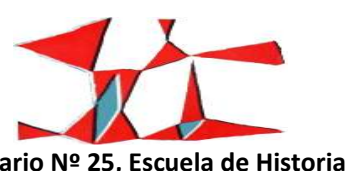


1894 cristalizaran en una organización estable. En abril de 1895 los socialistas recordaban a sus lectores que "los trabajos preliminares para constituir la Federación obrera (...) después de un par de meses se paralizaron y la Federación quedó en proyecto". Algún tiempo antes, una nota de Adrián Patroni lamentaba que, existiendo en la ciudad más de treinta sociedades gremiales de resistencia, éstas permanecieran aisladas y no tratasen "de reconcentrar sus fuerzas para que la acción común dé mayor vigor a la lucha contra la clase capitalista".22

Los socialistas vinculaban esta incapacidad para articular una federación de gremios con el debate sobre las huelgas parciales y generales. En efecto, consideraban que la generalización de conflictos huelguísticos no era necesariamente un fenómeno positivo: si bien mostraba una reactivación de la agitación de los trabajadores que era reivindicada, ponía de manifiesto asimismo la ausencia de una articulación entre las diferentes luchas parciales. ${ }^{23}$

Fue a partir de este balance crítico de la experiencia realizada desde mediados de 1894 que los socialistas impulsaron, en 1895, una Federación compuesta casi exclusivamente por los gremios en los cuales tenían una influencia política destacada. El 28 de marzo se realizó una reunión que contó con la participación de tipógrafos, hojalateros, herreros mecánicos, yeseros, carpinteros, constructores de carruajes y tabaqueros. Allí se nombró como secretario provisorio al socialista Aníbal Canavesio y se puso en discusión el proyecto de programa "que ya había sido presentado en septiembre de 1894, modificando algunos artículos". Las modificaciones eran muy pocas y tenían que ver con algunos de los puntos que habían sido discutidos en los meses previos. El artículo 7 se limitaba ahora a plantear la intención de "promover un análogo movimiento en las provincias". Más importante, se eliminaba por completo el artículo que disponía la "abstención" de todas las cuestiones políticas y religiosas. Ya sin los yeseros, uno de las pocas sociedades que no estaban orientadas directamente por los militantes socialistas, pero con el agregado de los fideleros y los toneleros, dos gremios dirigidos por activistas de esta orientación política, el

\footnotetext{
22 “Organización que se impone”; La Vanguardia; Año II, № 7; 16 de febrero de 1895.

23 "La federación obrera"; La Vanguardia; Año II, № 14; 6 de abril de 1895.
}

\section{4}

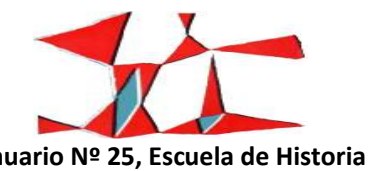


viernes 3 de mayo se realizó una nueva reunión en la que "quedó definitivamente constituida la Federación obrera y se nombró una comisión encargada de redactar los reglamentos internos". 24

En octubre, el "Comité Federal" de la nueva Federación publicó un manifiesto que llamaba a los trabajadores a adherirse a ella y desarrollaba los planteamientos y caracterizaciones que definían a esta nueva experiencia federativa. Como era habitual en estos casos, el texto partía de una denuncia de las condiciones de explotación, caracterizadas como "cada día más graves". Para enfrentar esta situación los trabajadores eran llamados a salir de la "indiferencia": el manifiesto recordaba que, "tal como ha dicho C. Marx, la emancipación de los trabajadores debe ser obra de los trabajadores mismos", e instaba a los obreros a sumar esfuerzos, integrarse a sus respectivas sociedades de oficio y contribuir al desarrollo de la Federación. El listado de sociedades confederadas confirmaba que se trataba de una iniciativa vinculada directamente a la militancia gremial de los socialistas: cinco de las once sociedades tenían su sede en el local de la calle Victoria 1398, domicilio del Centro Socialista Obrero, mientras que la de los constructores de carruajes lo tenía en el local del Vorwärts, la de fideleros en el local socialista del barrio de Balvanera y la de Tolosa en el local socialista de aquella localidad. El 12 de octubre, por ejemplo, la Federación invitaba a una conferencia en el local de la calle Victoria, acerca de "las ventajas de la Federación obrera": los oradores eran tres destacados dirigentes gremiales socialistas como Adrián Patroni, Aníbal Canavesio y Ramón Potau. ${ }^{25}$

\section{La experiencia de La Unión Gremial}

La constitución de una Federación obrera directamente vinculada al socialismo no fue, sin embargo, el único emergente del proceso de recomposición de las fuerzas obreras y articulación de las diferentes organizaciones que comenzó a desarrollarse a partir de 1894. En efecto, a partir de los intentos de unir fuerzas de gremios con distintas orientaciones políticas que caracterizó, como vimos, al intento federativo de 1894, surgió una publicación periódica Ilamada La Unión Gremial, cuyo análisis reviste un gran interés para completar el cuadro de los intentos de articulación de las sociedades de resistencia. El periódico, que comenzó a aparecer a comienzos de 1895, era publicado por una redacción constituida por delegados de

\footnotetext{
24 “Movimiento obrero. Federación obrera”; La Vanguardia; Año II, № 19; 11 de mayo de 1895.

25 "Movimiento gremial. Federación obrera"; La Vanguardia; Año II, № 41; 12 de octubre de 1895.
}

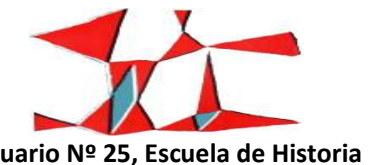


diferentes sociedades gremiales: si surgió como un resultado del compromiso precario que existía entre sociedades gremiales de diferente orientación política, se consolidó luego como un punto de referencia para los gremios adversarios a la Federación socialista.

El número 1 incluía un "Programa" como artículo principal, que estaba firmado por "La Redacción". Los redactores del periódico aclaraban que no pretendían "un lugar por mínimo que sea en el periodismo": su objetivo no era una publicación cuyos artículos tuvieran "las finezas de términos con que adornan sus escritos" los periodistas de oficio, sino un periódico con escritos "tan duros como dura es la mano callosa del trabajador", que fuera "fiel portavoz de las miserias" que embrutecían a los trabajadores. La Unión Gremial, se aclaraba en ese primer número, no defendería "ambiciones personales ni de ningún partido político, porque es harto probado que jamás han hecho nada, y jamás harán nada respecto al mejoramiento de las clases oprimidas", pero sí daría "una amplia propaganda a todo cuanto trate y discuta la economía social".

A pesar de estas explícitas definiciones en contra de las "ambiciones políticas", en los primeros números de La Unión Gremial participaban de la redacción delegados de las sociedades de resistencia influenciadas por los socialistas, y el periódico difundió la convocatoria a las primeras reuniones para la organización de lo que sería la Federación obrera de 1895. La Vanguardia saludó la salida del primer número y planteó que esperaban "que el colega sepa cumplir su cometido, cooperando a la organización de los trabajadores". ${ }^{26}$ Las contradicciones y el choque con los delegados que respondían al socialismo, no obstante, se hicieron inevitables muy rápidamente, sobre todo en un contexto en el cual, como vimos, los militantes socialistas avanzaban ya decididamente por el camino de organizar una Federación a partir de las sociedades gremiales afines a su línea política. La polémica abierta estalló con la publicación, en el número 3, de un artículo sobre el 10 de Mayo, aparecido originalmente en La Questione Sociale y de orientación explícitamente anarquista. La sociedad de mecánicos, afín a los socialistas, criticó la inclusión de un artículo de esas características, denunciando que violaba la decisión tomada por los impulsores del periódico de evitar tomas de posición en el terreno político. Los mecánicos anunciaron, a través de un manifiesto, que se retiraban del periódico y algún tiempo más tarde comenzaron a editar uno propio, titulado El Mecánico.

\footnotetext{
${ }^{26}$ La Vanguardia; año II, № 16; 20 de abril de 1895.

246

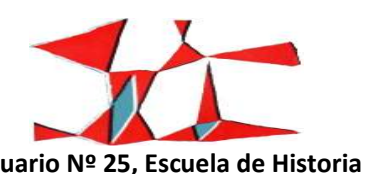

Revista Digital № 4, Facultad de Humanidades y Artes, Universidad Nacional de Rosario, 2013

ISSN 1853-8835
} 
En su número 5, editado el 6 de junio, La Unión Gremial respondió a las acusaciones de los mecánicos. En un artículo firmado por "un herrero", que se manifestaba como adversario de la dirección de su gremio, se argumentaba que los editores del periódico no habían violado su programa al publicar el artículo de La Questione Sociale por considerar que se trataba precisamente de una nota que "hablaba claramente contra todos los partidos políticos sin distinciones". Los militantes de orientación libertaria lograban presentar las cosas de un modo tal que el abstencionismo en términos de posicionamiento político era entendido en realidad como un cuestionamiento a una toma de posición afín al socialismo: la perspectiva política de los anarquistas podía presentarse, así, como una expresión "anti política", que por tanto no iba en contradicción con los principios del periódico gremial. ${ }^{27}$

Después de la ruptura de los mecánicos, las diferencias se profundizaron. Mientras los socialistas avanzaron, como vimos más arriba, en la construcción de una nueva Federación obrera integrada casi exclusivamente por sociedades gremiales afines a su línea política, La Unión Gremial se consolidó como un espacio alternativo que nucleaba a un conjunto de sociedades de resistencia opuestas al socialismo y más afines a la ideología libertaria. ${ }^{28}$ En julio se llegó a una polémica abierta entre ambos periódicos. En su número 7, publicado el 4 de julio, La Unión Gremial dedicó su artículo principal a discutir con el periódico socialista, que había editado una nota señalando que una denuncia de las que habitualmente salían en la sección "Abusos patronales" del periódico gremial había sido rechazada por sus redactores; según los socialistas, se debía a que el pequeño patrón que era criticado en la nota era de filiación anarquista. Más allá de lo cierto o no de la acusación, la tensión había llegado a un punto que hacía ya inevitable un enfrentamiento abierto entre dos publicaciones que hasta ese momento habían mantenido una relación de tensa coexistencia.

La Unión Gremial rechazaba la acusación de ser un periódico anarquista, argumentando que respondía a las ideas de los delegados de las sociedades de resistencia que contribuían financieramente para su publicación y agregaba que la causa de los ataques que les dirigía La Vanguardia era que la

\footnotetext{
27 “Protesta”; La Unión Gremial; № 5; 6 de junio de 1895.

${ }^{28}$ La lucha política se trasladó al interior de sociedades gremiales en las cuales coexistían militantes de ambas orientaciones políticas: el debate fue particularmente agudo por ejemplo en la sociedad de sastres, en la cual la influencia de los socialistas, fuerte en 1894, comenzó a ser cuestionada por militantes libertarios que influyeron en el acercamiento de la sociedad a la experiencia de La Unión Gremial.
}

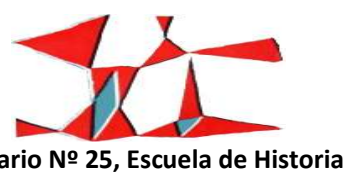


aparición de su periódico había reducido las ventas. ${ }^{29}$ Los socialistas respondieron en su número del 20 de julio: destacaban que La Unión Gremial "se había salido de sus casillas porque hemos criticado su conducta respecto a las sociedades obreras que representa", y destacaban que solo le habían dedicado una nota en uno de sus números, "no porque nos haya faltado motivo para hacerlo con frecuencia en sentido desfavorable a él, sino porque esperábamos que la enmienda nos evitaría críticas y polémicas enojosas entre obreros". Criticaban como una calumnia la acusación que reducía la discusión a un problema de ventas: los editores de La Vanguardia advertían que tenían "bastante más suscriptores que cuando empezó a publicarse La Unión Gremial" y señalaban que la suya era una sociedad obrera y que "sus redactores y administradores no cobran sueldo por los servicios que a ella prestan". ${ }^{30}$

Hacia mediados de julio de 1895 , en suma, ya comenzaban a quedar claros los campos de delimitación entre las diferentes sociedades gremiales de Buenos Aires. Mientras el reglamento de la Federación obrera había sido suscripto por las sociedades de toneleros, fideleros, constructores de carruajes, carpinteros, hojalateros, tabaqueros, herreros y tipógrafos, en La Unión Gremial aparecían como integrantes de la redacción las sociedades de albañiles, yeseros, pintores, sastres, marmoleros y tabaqueros. ${ }^{31}$ Los panaderos parecían tener una actitud prescindente respecto a ambos bloques.

Con la ruptura ya consumada, las críticas a los socialistas y a su programa se habían hecho más frecuentes en La Unión Gremial. La inicial "neutralidad" se fue transformando en una postura de denuncia de "la política" y de "los partidos". Ocasionalmente se publicaban, además, artículos de teóricos anarquistas y se difundían las publicaciones y folletos de La Questione Sociale. En el número 10, publicado a mediados de agosto, un artículo reclamaba a los obreros que rechazaran a "todo político", en tanto los políticos eran "enemigos y explotadores". En realidad, detrás de una fuerte crítica al socialismo y a la política en general se advertía la impronta anarquista, aunque no de manera abierta y siempre detrás de un fuerte componente gremialista. El artículo insistía en que los obreros no querían "saber de senadores, diputados, concejales, policías, ni de bichos, cualquier nombre lleven y que viven a plomo chupando nuestra sangre". Se observa, por un lado, un elemento anarco comunista -a cada uno según necesidad, de cada uno según su

\footnotetext{
${ }^{29}$ La Unión Gremial; № 7; 4 de julio de 1895.

30 "Notas"; La Vanguardia; Año II, № 29; 20 de julio de 1895.

${ }^{31}$ En el número 7 de este periódico, de hecho, se publicaba un breve comunicado que advertía su inquietud por la permanencia de los tabaqueros en la redacción, dado que estaban alineados con los socialistas.
}

248

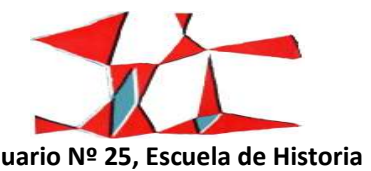

Revista Digital № 4, Facultad de Humanidades y Artes, Universidad Nacional de Rosario, 2013 ISSN 1853-8835 
posibilidad- pero también una reivindicación de las sociedades de resistencia y de las huelgas como eje de la propuesta organizativa, que contrastaba con los planteos de otros grupos libertarios. La idea era que los partidos y la política "tutelaban" a los trabajadores y eso debía ser rechazado:

(...) Desconfiad, compañeros, de toda política. No debemos ser más que obreros, y no debemos buscar más que combatir todo sistema capitalista, no ya deshacer uno para formar otro. No sé encontrar ninguna diferencia yo entre el dinero actual y los bonos valorizados que nos quieren regalar los socialistas. Queremos tener el derecho de producir tanto cuanto nuestras fuerzas intelectuales y materiales nos concedan, si las necesidades lo requieren, pero queremos también el derecho de consumir según la naturaleza con sus leyes absolutas y superiores nos impone.

(...) No queremos saber nada de partidos. Las sociedades de resistencia están formadas para mejorar en la actualidad las condiciones obreras, pero su fin es mucho más elevado, es sublime. Lo que debe preocupar más a los compañeros que se encuentren en condiciones de tener más convicciones, es el modo de propagar, sin crear más divisiones, pero propagar las necesidades de salirnos de toda clase de tutela. Todo ser que busque camino extraviado (como la política), es nuestro traidor, es un descarriado, es un camorrista. Hemos de buscar la emancipación por la vía recta y será suficiente un paso para obtenerla. (...) Un viva a todas las huelgas, a todos los obreros que saben combatir y vencer en beneficio del proletario, un muera a todos los mistificadores. ${ }^{32}$

A comienzos de 1896, un artículo del sastre De Cicco, otro de los principales redactores de La Unión Gremial, sostenía que la política era "el enemigo más acérrimo" del obrero, porque lo convertía en víctima de las "ambiciones personales" de los políticos y bloqueaba su libre iniciativa. No era el "parlamentarismo" lo que debía interesar a los trabajadores sino "la instrucción que nos deshace de toda superstición". De Cicco argumentaba que los gremios eran "por su origen independientes de toda política" y sostenía que para obtener sus reivindicaciones los obreros debían confiar solamente en sus fuerzas, "evitando pedir ni aceptar de limosna" e impulsando las huelgas para obtener aumentos salariales o reducción de la jornada de trabajo. El objetivo, en cualquier caso, no era la huelga en sí misma: según De Cicco,

\footnotetext{
${ }^{32}$ La Unión Gremial; № 15; noviembre de 1895.
}

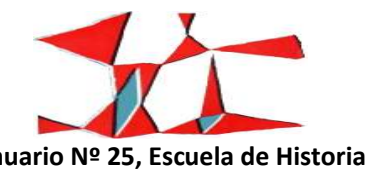


...la lucha emprendida por el proletariado en contra del explotador no se concluye con la huelga, ni tampoco se llega al fin deseado por medio de la política, esta conquista de felicidad que deseamos será cierta por la abolición de la propiedad particular, y con ella desaparecerá la ambición, y sin ambición nos amaremos recíprocamente, y trabajaremos no para embrutecernos sino para el bienestar de todos, sin amos que nos manden ni mercaderes que nos compren diariamente a bajo precio por la miseria creada por ellos mismos, y todo se conquistará no con la política parlamentaria sino confiando en el momento histórico de la revolución social. ${ }^{33}$

A comienzos de 1896, de todas maneras, el núcleo de gremios impulsores de La Unión Gremial estaba atravesando un período de dificultades. En los números 17, 18 y 19 hay referencias explícitas a la situación de retracción y crisis que podía observarse en las sociedades de sastres, pintores, albañiles, yeseros y marmoleros, que constituían en ese momento los gremios más activos en la redacción de la publicación. En el gremio de pintores se había producido una recuperación de la influencia socialista, que trajo como consecuencia el alejamiento del gremio de La Unión Gremial y la publicación de un nuevo periódico, llamado El Pintor. En las huelgas que estallaron en el verano de 1895, ninguno de los gremios referenciados en La Unión Gremial había tenido un papel activo. Encontramos en los números del período, por otra parte, un recrudecimiento de la polémica con los socialistas, que ponía de manifiesto el avance de estos últimos en diferentes sociedades gremiales. Un artículo de marzo de 1896 denunciaba por ejemplo "las dificultades simultáneas que surgen cada día por las ambiciones de los partidos políticos obreros" y sugería que "las sociedades de resistencia de este país hubieran sido más concurridas con la abolición del autoritarismo, discutiendo y poniendo en claro cada cual la propia iniciativa, sugerida del cerebro no del estómago como los falsos profetas, aspirantes a diputado". ${ }^{34}$ En lo sucesivo la aparición de La Unión Gremial se hizo más esporádica, poniendo de manifiesto estas dificultades: mientras el número 19 apareció en abril, el siguiente recién lo hizo a principios de junio y el 21 fue editado el 12 de julio. En éste, el último disponible, solo aparecían como integrantes las sociedades de albañiles, marmoleros, yeseros y mosaiquistas.

\footnotetext{
33 "Calamidad social”; La Unión Gremial; № 18; 6 de marzo de 1896.

34 ídem.
}

250

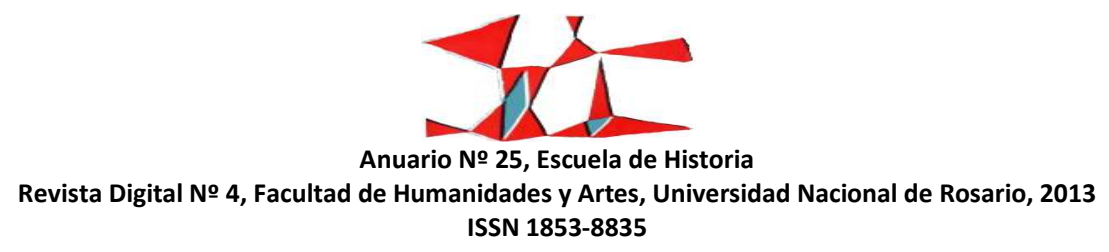




\section{La "Convención obrera" y el debate sobre la huelga general}

Aunque la experiencia de La Unión Gremial languidecía, durante los primeros meses de 1896 buena parte de las sociedades de resistencia de Buenos Aires que permanecían por fuera de la Federación avanzó en un intento de articulación más estable, que llevó el nombre de "Convención obrera". Se trata de una experiencia efímera y que no logró consolidarse, pero cuyo examen resulta importante porque echa luz sobre las relaciones de fuerza que existían entre las sociedades gremiales del momento y acerca de la dinámica de organización que tenía lugar por fuera de la experiencia de la Federación obrera orientada por los socialistas. La experiencia de la "Convención", además, presenta particular interés porque se articuló en buena medida en torno a una reivindicación de la huelga general como medida de lucha apropiada a la situación de los trabajadores en el período.

Si La Unión Gremial había actuado en cierta medida como un polo que aglutinaba a las sociedades gremiales que se mantenían al margen de la Federación, la estructuración de vínculos organizativos más estrechos entre las mismas avanzaba a un ritmo más lento. Si bien, por un lado, los planteamientos afines al anarquismo de la mayor parte de esas sociedades explican su mayor reticencia a avanzar en una centralización que era vista con recelo, los avances realizados por la Federación impulsada por los socialistas actuaba, por otro lado, como un factor de estímulo al desarrollo de cierta articulación entre las sociedades que buscaban enfrentar su influencia.

Así las cosas, el 19 de septiembre de 1895 La Unión Gremial informaba de la realización de reuniones por parte de los gremios no alineados con los socialistas "para discutir sobre el tema de la protección mutua en tiempo de huelga". El periódico indicaba que habían estado presentes delegados de los pintores, los picapedreros, yeseros, albañiles y marmoleros: debido a "la importancia que reviste el asunto y los limitados gremios allí representados", no se había avanzado en aprobar ninguna resolución definitiva, pero se había estudiado "con verdadero interés la proposición que se demuestra cada día más simpática y necesaria en una concreta afirmación de la protesta obrera" y se resolvió que los delegados llevasen el debate a sus respectivas sociedades.

En el anteúltimo número de La Unión Gremial, publicado el 4 de junio de 1896, salió un pequeño artículo que anunciaba que las sociedades de albañiles, marmoleros, yeseros, panaderos y estibadores

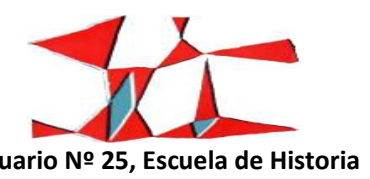


habían decidido "dar reuniones de propaganda para la huelga general de todos los gremios", para lo cual esperaban "el apoyo de todas las demás sociedades y obreros conscientes" y convocaban a una reunión para el domingo 7 de junio. Las argumentaciones en favor de la huelga general, de hecho, habían comenzado a aparecer en La Unión Gremial desde comienzos de 1896. Un artículo firmado por "Carlos P.", aparecido a comienzos de febrero, caracterizaba como inútiles a las huelgas parciales que estallaban en diversos gremios y planteaba la necesidad de unificarlas en una huelga general. El artículo constataba que "desde algún tiempo a esta parte", cobraban fuerza las huelgas que ponían de manifiesto "clara y patentemente que la masa obrera del mundo entero, va despertando de su letargo y empieza a comprender sus derechos que por ley natural pertenecen a todo hombre". Las huelgas parciales, sin embargo, nunca habían sido capaces de traer mejoras a los trabajadores: eran criticadas, además, por las limitaciones de sus reclamos. La alternativa era, entonces, dejar de lado "toda clase de huelga pacífica" e impulsar "las huelgas generales y violentas para de una vez por todas tomar nuestros derechos como productores que somos y vivir entonces en una nueva era de felicidad".

La iniciativa fue tempranamente criticada por los socialistas, que advertían que se trataba de una articulación de gremios adversaria de la Federación por ellos dirigida. La propuesta, en realidad, encubría según Patroni a aquellos que "a cada paso combaten las huelgas por creerlas de resultados contraproducentes, pero aconsejan la huelga general, como un medio seguro para obtener grandes mejoras para la clase obrera". ${ }^{35}$

Además de los gremios que se articulaban en torno a La Unión Gremial, un papel destacado en la experiencia de la Convención fue jugado por la sociedad de panaderos. En el número 5 de El Obrero Panadero se convocaba a las reuniones preparatorias con un extenso artículo que desarrollaba toda una caracterización de la situación del movimiento obrero de la época tal como lo interpretaban en la sociedad. La nota hacía referencia a "las huelgas que de un tiempo a esta parte se vienen verificando y el poco resultado alcanzado por casi todas ellas", situación que había llevado a la sociedad a "llamar a una reunión los representantes de todas las otras corporaciones obreras para tomar medidas aptas a evitar las huelgas parciales de cada gremio y provocar, cuando se crea oportuno, una huelga general de todos los gremios". La

\footnotetext{
35 "Reuniones de trabajadores"; El Tiempo; 2 de marzo de 1896.

252

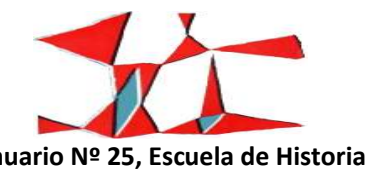

Revista Digital № 4, Facultad de Humanidades y Artes, Universidad Nacional de Rosario, 2013 ISSN 1853-8835
} 
huelga general era vista como el corolario que debía tener cualquier huelga iniciada por un gremio particular que encontrara un rechazo por parte de la patronal: de ese modo, según el órgano de los panaderos, "frente a la solidaridad de toda la clase obrera, la burguesía deberá ceder y declararse vencida". En clara referencia a los socialistas, El Obrero Panadero sostenía que quienes se oponían a esta idea eran aquellos "que trabajan para explotar la ignorancia de los trabajadores (...) los ambiciosos que quieren valerse de la clase obrera para ocupar un puesto preeminente en el mundo burgués, los farsantes de la política; aquellos que para engañar mejor a los pobres ilusos, a cada momento repiten que hablan en nombre de la ciencia". ${ }^{36}$

Durante el otoño de 1896 se desarrollaron las reuniones preparatorias: La Prensa informaba que el 14 de marzo tuvo lugar una reunión, a la cual estaban invitadas las sociedades de albañiles, panaderos, yeseros, marmoleros, carpinteros, vidrieros, talabarteros, estibadores, marineros, peones de la ribera, sastres, fideleros, constructores de carruajes y carpinteros galponeros. Una nueva reunión tuvo lugar el 26 de mayo, y el domingo 7 de junio se convocó a una conferencia impulsada por "las sociedades iniciadoras de la Convención obrera": panaderos, albañiles, yeseros, marmoleros y estibadores. Según las crónicas, la reunión se realizó en el jardín del Pasatiempo y contó con una importante concurrencia de más de mil personas. ${ }^{37}$ La discusión fue abierta por el secretario de la sociedad de panaderos, y luego tomó la palabra el de la sociedad de albañiles, Fernando Balmelli. Siguiendo la línea desarrollada en los trabajos preparatorios previos, Balmelli argumentó que las huelgas parciales no habían dado "sino resultados ridículos" y que los trabajadores debían "meditar y estudiar con detención la posibilidad de una huelga general, que podría iniciarse después de ser preparado suficientemente el terreno". Como era habitual en las reuniones y asambleas donde influían los militantes anarquistas, se declaró "la palabra libre" y los concurrentes fueron invitados a expresar sus opiniones: según la crónica la reunión se extendió durante algunas horas, hasta terminar con incidentes "cuando se le ocurrió a un desconocido subir a la mesa y

\footnotetext{
36 "Convención de las Sociedades Obreras de Resistencia”; El Obrero Panadero; Año II, № 5; 8 de marzo de 1896.

37 "Convención de las sociedades obreras de resistencia"; La Prensa; 14 de marzo de 1896 y "Movimiento obrero"; La Prensa; 8 de junio de 1896.
}

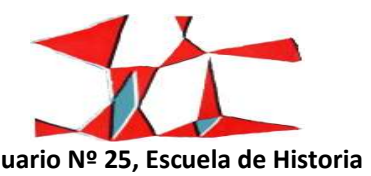


desafinar hablando de bombas y cuchillos". En ese momento intervino la policía y se produjeron incidentes cuando muchos de los concurrentes defendieron al orador, evitando que fuera detenido. ${ }^{38}$

\section{Conclusión}

A pesar de su importancia, la reunión del 8 de junio fue en realidad el punto más alto al que pudo llegar la Convención, que fue desarticulándose en los meses sucesivos, debido fundamentalmente a las contradicciones que atravesaban a los diferentes sectores que la conformaban. A pesar de sus límites, tanto la experiencia de la Convención como la del periódico La Unión Gremial ponían de manifiesto de todos modos que hacia mediados de la década de 1890 ya estaban planteadas buena parte de las discusiones que marcarían a todo un período del movimiento obrero local, en torno a cuestiones de enorme importancia como la articulación de las diferentes sociedades gremiales, la actitud a adoptar frente a las huelgas y la conveniencia o no de la huelga general.

Se trataba de un conjunto de discusiones que mostraban los avances y los límites del proceso de unidad de la clase obrera que tenía lugar en esos años finales del siglo XIX en la ciudad de Buenos Aires. Para mediados de la década de 1890, los trabajadores de la ciudad de Buenos Aires habían desenvuelto una acelerada experiencia de avances organizativos en torno a sociedades que los agrupaban para defenderse de los avances patronales y obtener sus reivindicaciones. Si bien en algunos casos las sociedades habían precedido a los conflictos, en buena medida fue la propia agitación huelguística la que sentó las bases para que las primeras comisiones y agrupamientos obreros, surgidos para llevar adelante un determinado reclamo, se convirtieran en la base de sociedades gremiales más estables. A través de la difusión de circulares y manifiestos, de la organización de piquetes de huelga, del mantenimiento de cajas de resistencia y de la realización de reuniones y asambleas periódicas, las nacientes sociedades gremiales de la ciudad se iban consolidando en diferentes oficios: si el contexto de reflujo de los años 1890 a 1892 marcó un límite a ese primer desarrollo, muchas de ellas fueron capaces de mantener una actividad permanente y el nuevo ascenso de luchas que tuvo lugar a mediados de la década mostró un cuadro en el cual la mayor parte de los gremios de la ciudad contaba con una asociación de resistencia.

\footnotetext{
38 "Movimiento obrero"; La Prensa; 8 de junio de 1896.

254

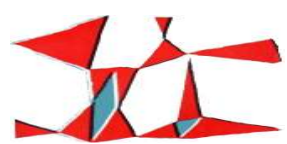

Anuario № 25, Escuela de Historia

Revista Digital № 4, Facultad de Humanidades y Artes, Universidad Nacional de Rosario, 2013 ISSN 1853-8835
} 
En este artículo hemos mostrado el modo en que en este mismo período esas sociedades gremiales de diferentes oficios establecieron muy pronto relaciones entre sí. Los primeros en darle impulso a esta iniciativa fueron los militantes socialistas, que ya en 1890 intentaron impulsar una Federación obrera que tuvo el indiscutible mérito de plantear la necesidad de que las diferentes sociedades se vincularan entre sí. Sin embargo, como hemos intentado mostrar en este trabajo, incluso desde las filas opositoras a los socialistas se planteó la cuestión de la articulación entre los diferentes gremios, en lo que constituye un aspecto inexplorado por una historiografía previa que estuvo dominada por los señalamientos realizados por los propios historiadores del Partido Socialista.

En efecto, en un cuadro en el estallaban huelgas impulsadas por numerosas sociedades gremiales de diferentes oficios y con distintos grados de organización, se fueron desenvolviendo diferentes posiciones acerca de la necesidad de articular la agitación obrera. Los socialistas reivindicaban las huelgas en la medida en que expresaban un desarrollo en la conciencia de clase y sacaban a los trabajadores de la pasividad, pero consideraban que se trataba de una forma de lucha arcaica. Para ser exitosas, las huelgas debían prepararse con cuidado y ser siempre parciales, es decir concentradas en un determinado oficio o en ciertos patrones dentro de una determinada rama, asegurando mientras tanto que el resto de los trabajadores colaborase con su apoyo y solidaridad para el triunfo de la huelga. La huelga general era por lo tanto criticada, en la medida en que se la consideraba una medida sin perspectivas de éxito, que solo lograría debilitar la fuerza acumulada por las sociedades obreras. La articulación entre las diferentes sociedades obreras era un objetivo fundamental para organizar de la mejor manera posible la actividad huelguística: la Federación buscaba en este sentido centralizar las fuerzas obreras para impulsar con éxito las diferentes huelgas parciales y representaba además un paso más en el desarrollo de la conciencia de clase, que mejoraba el campo para la construcción de la fuerza política, el partido, que era visto como la herramienta que permitiría el mejoramiento de los trabajadores, a través de la acción política.

Los gremios nucleados en torno al periódico La Unión Gremial, muchos de los cuales confluirían poco después en la experiencia de la "Convención obrera", ofrecían una caracterización y una línea de intervención distintas. Partían, al igual que los socialistas, de una valoración crítica de la sucesión de huelgas desarticuladas y sin relación entre sí que surgían en diferentes gremios obreros de la ciudad. Esa crítica, sin embargo, los llevaba a conclusiones diferentes: en este caso se planteaba un cuestionamiento global de las

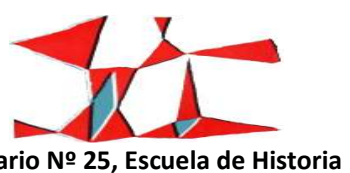


huelgas parciales y una reivindicación de la huelga general. La articulación de los diferentes gremios, que se planteaba con un nivel de centralización y reglamentación menor que el impulsado por los socialistas, era entendida en este caso como un mecanismo para promover una paralización del trabajo en todos los oficios.

Detrás de las discusiones en torno a la unidad de las diferentes sociedades de resistencia, como puede advertirse, estaban planteados algunos de los principales debates entre las diferentes corrientes políticas de la izquierda en este período temprano, muchos de los cuales marcarían al movimiento obrero local por un largo período.

Recibido: 5 de julio de 2013 Aprobado: 2 de Septiembre de 2013 Versión final: 11 de octubre de 2013 